\title{
The Impact of Beauty Bloggers' Online Review towards Shopping Tour Interest of Cosmetic Products in Jakarta
}

\author{
Rina Fitriana ${ }^{1 *}$ Amrullah², Intan Suryani ${ }^{3}$ \\ 1 Politeknik Sabid \\ 2,3 Sekolah Tinggi Pariwisata Trisakti \\ *rinafitriana@polteksabid.ac.id
}

\begin{abstract}
This study is aimed at finding out the impacts of beauty bloggers' online review in encouraging women' interest to carry on shopping tours on cosmetic products in Jakarta. The study uses descriptive method by administering a questionnaire to 100 women respondents who carry on shopping tours on cosmetic products in Jakarta. The findings show that that beauty bloggers' online review possesses a strong relationship as many as 0.682 towards the shopping tour interest of cosmetic products in Jakarta which as many as $46.5 \%$. Beauty bloggers share information and recommendations based on their own experiences by using blog with the contents in the forms of captions, photos, and videos about a certain cosmetic product so that it encourages shopping tours on cosmetic products. Therefore, in the present study, H0 is rejected and $\mathrm{H} 1$ is accepted, in which $\mathrm{t}$ count is $9.235>\mathrm{t}$ table 1.984. Thus, it can be concluded that the impacts of beauty blogger' online review towards the shopping tour interest on cosmetic product in Jakarta indeed existed.
\end{abstract}

Keywords: online reviews, interest, shopping tours, cosmetic products, beauty bloggers 


\section{A. Introduction}

Commerce in Jakarta has been the center for huge money turnover so that about $70 \%$ of money circulates in this city. This city also has long-term and simultaneous tourism attraction since it has potentials such as natural tourism, cultural tourism, culinary tourism, and shopping tourism, which are attractive and various so that it is acceptable to compete in international markets. One of the tourism attractions in Jakarta is shopping tourism, which is a relevant component for choosing destinations and preparing the tourism trips. Considering the shopping tourism development in Jakarta, the society also keeps up with the current development in various aspects.

Nowadays, the use of internet and social media in the digital era is also improving. People often search for information about everything through internet and social media as well. People's freedom to make any contents or citizen journalism also influences the tourism industry. The development of the digital era has become an opportunity and is utilized by the beauty bloggers to share current information on various skin care and beauty clinics through blogs, Instagram, Youtube, and other media. In Indonesia, currently, there are around $3,8 \%$ or about 3 billions active users on internet and the number is still counting on with various media to share opinions and is supported by the development of technology to make attractive contents. In fact, reading a content that reviews a product or watching a video will encourage one to carry on shopping tours. Through the contents made by the beauty bloggers that include various information, such as tips and tricks for applying cosmetics, people believe that the reviews from the beauty bloggers have reflected the popularity of a product of cosmetics.

In Indonesia, there are beauty bloggers who have inspired people to know more about skin care and beauty clinics, especially cosmetic products which have been parts of women' needs. The following is a list of Top Five Indonesian Beauty Bloggers according to Alexa application on November 2018.

Table 1: Top Five Indonesian Beauty Bloggers

\begin{tabular}{llll}
\hline NO. & BLOG & LINK & RANK \\
\hline $\mathbf{1}$ & Tasya Aile & $\underline{\text { http://www.hellosasyachi.com/ }}$ & 138,759 \\
$\mathbf{2}$ & Lizzie Para & $\underline{\text { http://www.lizzieparra.com/ }}$ & 103,748 \\
$\mathbf{3}$ & Stella Lee & http://www.stellalee.net/ & 1119,099 \\
$\mathbf{4}$ & Harumi Sudrajat & $\underline{\text { http://www.mytipscantik.com/ }}$ & 135.551 \\
$\mathbf{5}$ & Andra Alodita & http://www.alodita.com/ & 221,180 \\
\hline
\end{tabular}

Sumber : https://www.romelteamedia.com 
Other than that, in carrying out shopping tours, there are internal and external factors that encourage someone to shop. The internal factor comes from one's own self that estimate one's needs of a cosmetic product. Meanwhile, the external factor may come from reviews, the products' quality including the price and the packaging appearance, video, and other information that are shared by others. In the present study, others mean the beauty bloggers in Indonesia who are considered as having more experience and understanding of the variants of the existing cosmetic products

\section{B. Literature Review}

\section{User Generated Content and Blog}

Blog is a kind of User Generated Content (UGC) which is internet content containing information that is created by users or often referred to as "a user" in the communication media (Bruns, 2016:1). The examples observed of UGC are posts by uploading photos and posting about a product reviews on social media such as Instagram or special applications like applications like Zomato, et cetera.

Enterprise (2016:1) states that blogs is an acronym of website log, or weblog. This is a kind of website that contains writings that are published periodically and continuously which express ideas, thoughts, opinions, experiences, adventures, and so on. The writings are frequently called postings, entries, or articles. Hakim (2008:1) defines blog as a terminology that comes from the word weblog. Web is defined as a note written in the form of web (log=notes). Thus, formally, blog is a website that contains contents in a reversed sequence of time and consists of postings. The term blog means a journal or article that is written by someone who is called a blogger, in which the activity of writing journals or articles in a blog is called blogging.

Nowadays, there are plenty kinds of blogs, started from personal blogs, to blogs on certain fields, such as blogs on politics, health, literature, religion, directions, and many more. One of the kinds of the blogs that is now everyone's passion or hobby and is freshly discussed is one that is called beauty blog. The concept of beauty blog is related to the cosmetic and beauty care persons that own personal needs as well. In his thesis, Kroll (2015) has identified some aspects contained in beauty blogs, such as:

1. Reviews of cosmetic and beauty products.

2. Tips and tricks to apply cosmetic products, such as techniques and the tools for applying it.

3. Self-experiences

4. Cosmetic product promotions.

5. Beauty blogs is related to skin care and beauty clinic, like cosmetic products, skin care, and make up tools.

Everything that beauty bloggers share on their blogs are usually attractive for their review readers, since they review and give information about the 
strengths and the weaknesses of certain cosmetic products. The shared information are persuasive so that they will build a brand image indirectly that can encourage someone to buy the products. However, some of the beauty bloggers' online reviews inhibit people from buying certain cosmetic products, since they give statements that there are deficiencies in the products. Based on the explanation above, the bloggers' content in the present study are related with beauty bloggers' review towards the cosmetic products that can be influential to one's shopping desire.

\section{The Functions of Blog}

Enterprise (2016:2) states that blogs have become a media to make contents, either for personal purposes as the media for political, economical, social, and cultural purposes, or other purposes. The functions of blog are as follow.

1. As a media to share information easily

2. As a means to practice one's skill and creativity of writing

3. As a media for communication and socialization

4. As a means for self-expression

5. As a means to increase income

By the various functions of blog, some blogs are interactive, some others are non-interactive. Interactive blogs present information and there is the comment section that facilitates the viewers to give comments or ask questions related to the captions, photos, or videos in the blog. Meanwhile, non-interactive blogs is a kind of one way information from the blog's authors to the readers or viewers without providing the comment section for commenting or asking questions.

\section{The Content of Blog}

Blog contents are resulted from one's self-expression and thoughts through written content as one of the alternatives. Enterprise (2016:2) says that the content making is purposed to be informative and able to convey one's desire and thoughts which include the blogger's reviews and opinion. Besides, the contents in blogs are conveyed by keeping up with current and trending issues in mass media, social media, online printed media, or electronic media.

\section{Definitions of Internet, Online Media, and Social Media}

Allan (2005:12) states that internet is a group of computer networks that interrelate physically and has the ability to read and decipher certain communication protocols which is called Internet Protocol (IP) and Transmission Control Protocol (TCP). Romli (2012:34) defined online media as a kind of media or a communication facility that can be accessed through internet connection which takes the forms of writings, photos, videos, and audios. Online media categories cover e-mails, blogs, websites, mailing list, social 
media, and social networks including WhatsApp and Line. Social media is online media facilitating people to interact with each other. It encourages social interaction using technology on the basis of web to provide interactive dialogues.

\section{Definition of Online Review}

The internet nowadays has been so rapidly developed that it is showed that technology has led to media on the basis of online. According to the market research institution, as stated in e marketer Tekno Kompas, in 2018, there have been estimated about 120 billion internet users, or netters, in Indonesia. This puts Indonesia in the Top Six countries with huge amount of internet users in the world. Zhao et.al. (2015) stated that there are six conditions of online reviews, namely : (1) usefulness of online review, in which online reviews influence the process of decision making in purchasing, (2) Reviewer expertise, this means that on the cyber world or internet, one that shares his/her writing of various information invites others to certain discussion for his/her experience in using the product so that he / she is considered an expert. (3) timeless of online review, this means one's consistency in sharing information on internet websites in which various information, both real facts or hoaxes, will influence the readers. (4) Volume of online review, this means the amount of comments or testimonies of a reviewer that review a product or service in rating the product. (5) Valence of Online review, this means the message that is given through an online review that contain positive content that will influence the decision making for purchasing a product or service, or negative review content that is spread which show one's disappointment based on his/her experience. (6) Comprehensiveness of online review, this means the completeness of online review will create one's desire to own or purchase a reviewed product or service.

\section{Definition of Shopping Tourism}

Timothy (2005:42) defines shopping tourism as a kind of tourism that fulfill consumers' needs and desires, in which it is defined as an activity of touring by visiting shopping sites to purchase retailed products. The components that encourage the shopping tourism according to Kinley (2012:54) include:

1. Physical planning strategy. This is related to the planning for utilizing an area at a shopping tourism location which is optimally coordinated and the improvement of the location that will influence the adjustment of shopping center location.

2. Merchandising. This means the selection of goods based on products, brands, and quality that will encourage one's desire to visit and purchase the products.

3. Shopping Destination strategy. This is a concept in shopping tourism industry that is related to modern shops in one shopping center called malls. The malls include modern shopping venue design and layout display. 
Based on the explanation above, the shopping tourism interest can be encouraged by internal factors that come from one's self, such as the desire or the needs on certain goods, emotional factor such as for self-existence, and the satisfaction on the previously used products. However, the external factors also influence the shopping tourism activity, such as friends' recommendation or the experts of the products. Moreover, beauty bloggers' online reviews encourage someone to purchase current cosmetic products, as well as the promotions, the offered price of products, the unique packaging, and other factors. Products discussed in the present study are those of cosmetics. Cosmetic means treatment substance which is composed of various chemical substances, some of them are natural, some others are synthesized. Cosmetics are used for improving one's appearance and body fragrance, usually called make up.

\section{Research Methodology}

\section{Methods and Research Analysis Unit}

The present study employes descriptive quantitative method. Descriptive method means a study that gathers data to test the research questions or hypothesis which are related to the current situation. The purpose of descriptive study is to describe facts and the characteristics of objects or subjects systematically and to study it properly (Wes, 1982) in Darmawan (2013:38).

Quantitative research means a process to investigate knowledge by using data in numbers as the tool to find information that we want to know (Margono, 1997, in Darmawan, 2013:37). Unit of analysis is defined the unit that is being observed or explained (Kusmayadi and Sugiarto, 2000:73). It can be individuals, organization groups, societies, someone's masterpiece, institutions, and so on. The unit of analysis in the present study is viewers in Jakarta.

\section{Variables and the Measurements}

Kerlinger (2006:49) defined variables as the constructs that are being studied that have various values. Independent variable is the variable that becomes the cause for the change of the dependent variables. The following are variables, sub-variables, and the measuring scales in the present study. 
The Impact of Beauty Bloggers' Online Review towards Shopping Tour Interest of Cosmetic Products in Jakarta

Table 2: Variables and Variable Operational Factor Measurement Scale

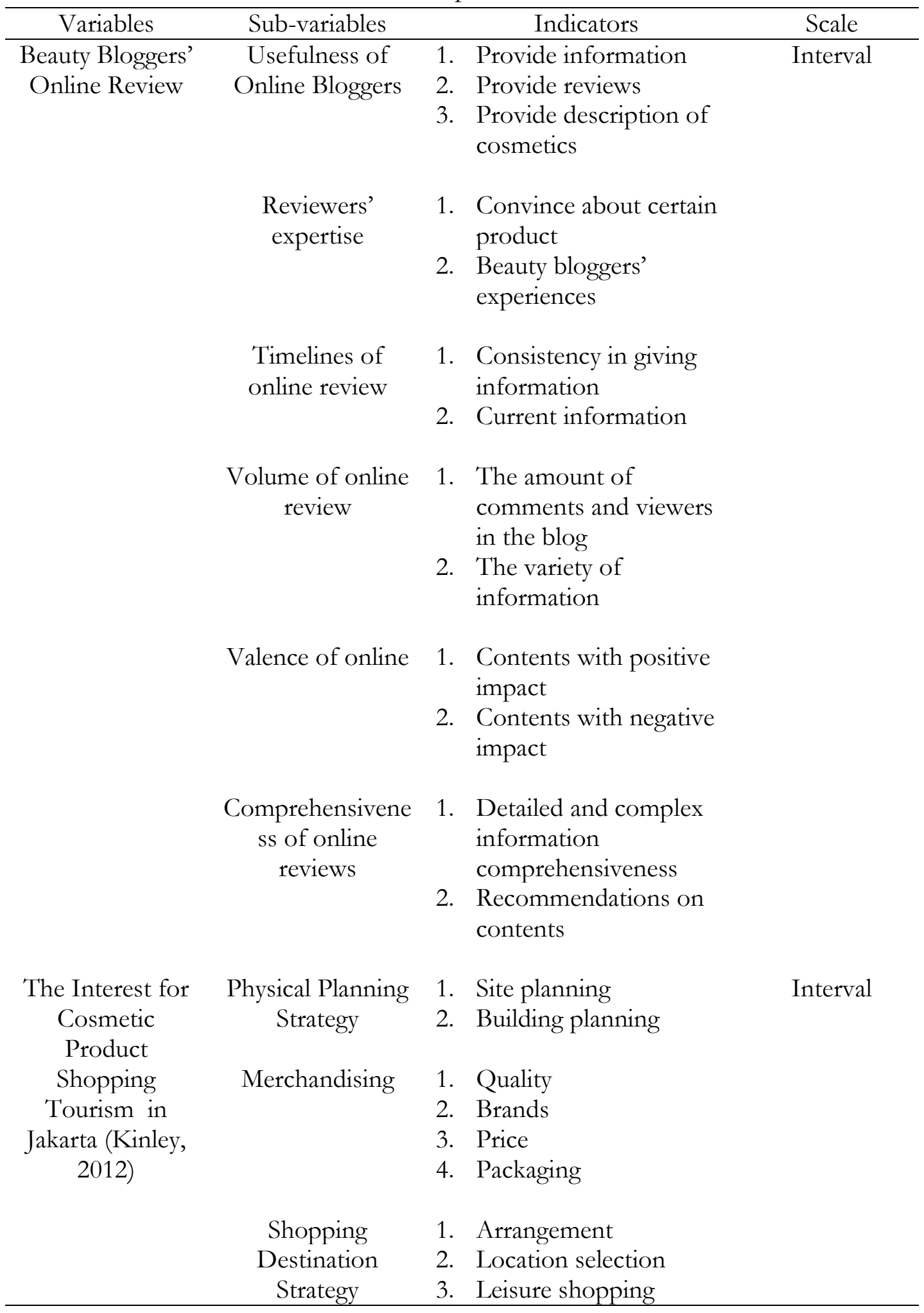


Nominal scale means the scale that classifies a phenomenon into two or more categories. The category does not shot the rangking and it is usually stated in numbers or alphabets (Kusmayadi and Sugiarto, 2000:166). Ordinal scale is category classification based on the ranking. This ranking is arranged from the highest to the lowest or vice versa (Kusmayadi and Sugiarto, 2000:166). Interval scale possesses the similar features with those of ordinal scale. The difference lies that in interval scale, the ranking of difference on one category and other category is acknowledged (Kountur, 2007:51). The variable measurement utilized in the present study was likert scale. Likert scale is a tool to measure attitudes of a positive condition to the negative rate, to show to what extent the agreement or disagreement of the stated questions of the researcher (Kusmayadi and Sugiarto, 2000: 94).

Table 3: Likert Scale

\begin{tabular}{lc}
\hline \multicolumn{1}{c}{ Alternatif } & Skor \\
\hline Strongly Agree & 5 \\
Agree & 4 \\
Doubt & 3 \\
Disagree & 2 \\
Strongly Disagree & 1 \\
\hline Source: Kusmayadi and Sugianto (2000:94)
\end{tabular}

Responding to the statements in Likert scale, the respondents determine an agreement/disagreement of a statement by choosing one of the options provided in five scale option with scores as follow:

\section{Sampling Procedure}

Population is the entire element of one kind, yet is distinguished one another for different characteristic value (Kusmayadi, 2004:20). The population in this study is all women visiting top 5 (five) top beauty blogs in one day which is 1.881 according to www.statshow.com. Samples are parts of population that are considered represent the characteristics of a population (Kusmayadi, 2004:20). The technique used to gather the data is called sampling technique. To determine the number of sample can be gathered by using a formulation that is developed by Slovin (1990) in Kusmayadi and Sugiarto (2000:74).

$$
\begin{aligned}
& n=\frac{N}{N / 1+N(e)^{2}} \\
& n=\frac{1881}{1+\left[1881(10 \%)^{2}\right]}
\end{aligned}
$$




$$
n=\frac{1881}{19,81}
$$

$$
n=94,952044422=100, \text { in which }
$$

$\mathrm{N} \quad=$ Population

$\mathrm{n} \quad=$ samples

$\mathrm{E} \quad=$ Margin Error (estimated error)

The study uses purposive sampling that is a technique of collecting samples based on purpose. The researcher selects samples for certain considerations (Kusmayadi, 2004:66). The collected data then clarified in the form of tabulated data, after that the data will be explained and interpreted descriptively.

\section{Result}

\section{Validity Test}

Based on the result of validity test conducted, the instrument for both variables are valid because $r$ count $>r$ critical, by the value of $>0.195$.

\section{Reliability Test}

It is found that the value of Cronbach's Alfa for variable X is 0.933 , which is bigger than 0.6 , which indicates that all instrument used in variable $\mathrm{X}$ is reliable. Meanwhile Cronbach's Alfa for the Variable Y was 0,861, which also shows that the instrument is reliable.

\section{Descriptive Statistic Test}

It is found that the highest average in variable $\mathrm{X}$ is on the usefulness of online review sub-variable with the value of 4.27 that shows that the viewers consider the review to be useful for them in helping them choosing the cosmetics they want. On the Variable $\mathrm{Y}$, the highest average value is on the merchandising sub-variable with the value of 4.16.

1. Average (Mean) of the value of beauty bloggers' online review is 4.02 from total 100 data. This shows that the value of beauty bloggers' online review is in category of Good.

2. The average (Mean) of the shopping tour interest for cosmetic products is 3.87 from the total of 100 data. The test result shows that the interest for shopping tour of cosmetic products was in the category of Good.

\section{Correlation Coefficient Test}

Based on the result of data analysis, it is stated that the result of the relationship between the two variables, the variable of beauty bloggers' online review is 0.682 towards the interest for shopping tour of cosmetic products. The 
beauty bloggers' online review has succeeded in influencing the interest for shopping tour of cosmetic products. The result of correlation coefficient test with the significant output found that the beauty bloggers' online reviews (X) and the interest for shopping tour of cosmetic products $(\mathrm{Y})$ is at the interval of $0.600-0.799$ that is categorized as strong and significant. Thus, it shows us that beauty bloggers' online review has a big impact on the shopping tour interest of their viewers.

\section{Regression Coefficient Test}

The result for regression coefficient test is 0.327 . It states that every $1 \%$ addition on the beauty blogger's online reviews will improve the interest for shopping tourism of cosmetic products for as much as 0.327 . This is due to the total numbers are positive, thus it is stated that the relationship between the two variables is positive and linear, in which beauty bloggers' online reviews gives a positive impact towards the interest for shopping tourism of cosmetic product.

\section{Determination Coefficient Test}

Based on the data analysis, it was found that the value of determination coefficient was $46.5 \%$. This is stated that the variable of beauty bloggers' online review (X) impacts toward the interest for shopping tourism of cosmetic products $(\mathrm{Y})$ as many as $46.5 \%$. Therefore, the rest $(53.5 \%)$ of the interest for shopping tourism of cosmetic product is influenced by factors other than beauty bloggers' online review. It shows that although beauty bloggers' online review has an impact on the shopping interest, it is not the only factor that impacts on it. There are some other factors such as discount, promotion, advertisement and so on that may also influence the shopping interest of the viewers, although those other factors are not discussed in this research.

\section{Hypothesis Test}

Based on the data analysis, it was found that the online reviews of beauty bloggers had the t count as many as 9.235 with the significant value of 0.000 and the $\mathrm{t}$ table $(100-1(\mathrm{X}) 1=98)$ was as many as 1.984 . With the result, it can be concluded that the $\mathrm{t}$ count $>\mathrm{t}$ table, therefore $\mathrm{H} 0$ was rejected and $\mathrm{H} 1$ was accepted. Thus, this means that there are the impacts of online reviews of beauty bloggers towards the interest for shopping tour of cosmetic products in Jakarta.

\section{E. Discussion}

According to the results of the data analysis, the validity of $\mathrm{r}$ count $>\mathrm{r}$ table, therefore it is stated as reliable, in which the answers of the respondents were stable with the Cornbach's Alfa $>0.60$, the variable of beauty bloggers' online review is as many as 0.933 and the variable of the interest for the shopping tour of cosmetic products is 0.861 . 
The result of SPSS shows that the entire average of the variable of beauty bloggers' online review is 4.02 with the highest average on the sub variable of usefulness of online reviews of beauty bloggers with the statement of "I got useful information from reviews of beauty bloggers". Getting some useful information could be the main reason why many women involved in this research like to view the blog. If they consider the information useful for them, it proves that one of the aspects of bloggers' review, which is to spread the information about a product, has been fulfilled. It also indicates that the information shared by the bloggers about the strength and weakness of the product considered more truthful than any kinds of advertisement. It happens possibly because the viewers believe that the bloggers has tested the product by themselves and has no financial advantage concerning the sales of the product. Therefore by having the information concerning the product, they will be able to choose what cosmetic products suit them.

The lowest value in variable of beauty bloggers' online review comes from the sub-variable of valence of online reviews. It concerns about the respondents who agree that they get negative information from the beauty bloggers. Thus, the beauty bloggers are suggested to improve their capability and credibility in providing complete and recommended information. This can be done by knowing more about a certain product of cosmetics on first hand so the readers can be more convinced in keeping up with the recommendations from the beauty bloggers.

The result of the descriptive analysis states that the average of interest for shopping tour of cosmetic products in Jakarta is 3.87 with the highest value on the sub-variable of merchandising, with the statement of "after reading reviews of beauty bloggers, I got interested in buying cosmetics and pay attention to the quality of the products with affordable price, interesting package, and certain brand". It has been stated before that the review contains some useful information that would show the product's strengths and weaknesses. By having such information, the viewers are able to compare one another and to consider what products she actually needs. We may conclude that some factors such as brand, packaging and price would still be the consideration for the viewers to choose a product. However, it is undeniable that their knowledge about the quality of a product, the brand that is more favorable, and so on gained from the review. Therefore, again, it proves that the beauty bloggers play a big role in encouraging the viewers' interest to shop and inspiring their cosmetic preference.

The result of the $\mathrm{t}$ hypothesis reveals that $\mathrm{H} 0$ is rejected and $\mathrm{H} 1$ is accepted which is stated that there are the impact of beauty bloggers' online review towards the interest for shopping tour of cosmetic products in Jakarta, with the result of $\mathrm{t}$ count was $9.235>\mathrm{t}$ table 1.984 and the impact as many as $46,5 \%$ towards the interest for shopping tour of cosmetic products in Jakarta. It shows that the bloggers' review has a significant strong impact toward shopping tour interest of cosmetic products in Jakarta, although it is not the only factor. 
There must be several other factors that impact on it, such as advertising and sale, which are not discussed in this research.

\section{F. Conclusion}

We may conclude that based on the result of data analysis, beauty bloggers' online review indeed has a positive and significant impact towards shopping tour interest of cosmetic products in Jakarta. The bloggers do not only encourage the viewers to have a shopping interest, but inspire them in their cosmetics preference as well. Since the beauty bloggers proved to have such an impact, it is important for them to always provide their viewers useful and reliable information concerning cosmetic products they review. This result also strengthens the idea that actually word of mouth, one of which is in the form of online review, is obviously powerful in marketing.

\section{REFERENCES}

Allan. (2005). Pengertian Internet dari Asal-Usul dari Kata Internet. Surabaya: Indah. Arikunto, Suharsimi. (2002). Metodologi Penelitian. Jakarta: Rineka Cipta.

Arikunto, Suharsimi. (2010). Prosedur Penelitian: Suatu Pendekatan Praktek. Jakarta: Rineka Cipta.

Berapa Jumlah Pengguna Internet Indonesia (2018) https://tekno.kompas.com/read/2018/02/22/16453177/berapa-jumlahpengguna-internet-indonesia, [accessed on March 31 2020].

Bruns, Axel. (2016). The International Encyclopedia of Communication Theory and Philosophy. USA: John Wiley and Sons Inc.

Darmawan, Deni. (2013). Metode Penelitian Kualitatif. Bandung: Penerbit Rosda

Enterprise, Jubilee. (2016). Otodidak Membuat Blog dengan Blogger. Jakarta: PT Elex Media Komputindo.

Ghozali, Imam. (2012). Aplikasi Analisis Multivariate dengan Program IBM SPSS 20. Semarang: Badan Penerbit - Universitas Diponegoro.

Hakim, Rachman. (2010). Cara Cerdas Mengelola Blog. Jakarta: PT Elex Media Komputindo.

Kerlinger. (2006). Asas-Asas Penelitian Behaviour. Edisi 3, Cetakan 7. Yogyakarta: Gadjah Mada University Press

Kinley, T. R., Forney, J. A., \& Kim, Y. K. (2012). Travel Motivation as A Determinant of Shopping Venue. International Journal of Culture, Tourism and Hospitality Research, 6(3), 266-278.

Kountur, Ronny. (2007). Metode Penelitian untuk penulisan Skripsi dan Tesis, edisi revisi. Jakarta: Penerbit PPM.

Kusmayadi, (2004). Statistika Pariwisata Deskriptif. Jakarta:. Gramedia Pustaka Utama. 
The Impact of Beauty Bloggers' Online Review towards Shopping Tour Interest of Cosmetic Products in Jakarta

Kusmayadi dan Sugiarto, Endar. (2000). Metodologi Penelitian dalam. Bidang Kepariwisataan. Jakarta: PT.Gramedia Pustaka Utama.

Kroll, Kalle Roman Lucas. (2018). (PDF) Why do beauty bloggers recommend and influence? $\quad$ Available from: https://www.researchgate.net/publication/280097248_Why_do_beauty_ bloggers_recommend_and_influence [accessed Mar 31 2020].

Romli, Asep Syamsul M. (2012). Jurnalistik Online: Panduan Praktis Mengelola Media Online. Bandung : Nuansa Cendikia.

Sugiyono. (2012). Metode Penelitian Kuantitatif Kualitatif dan R\&D. Bandung: Alfabeta.

Top Five Indonesian Beauty Bloggers, https://www.romelteamedia.com, [accessed June 26 2019]

Timothy, Dallen J. (2005). Shopping Tourism, Ratailing and Leisure. Channel View Publications.

Wardiyanta. (2006). Metode Penelitian Pariwisata, Yogyakarta : ANDI.

Zhao, X., Wang, L., Guo, X \& Law, R. (2015). The Influence of Online Reviews to Online Hotel Booking Intentions. International Journal of Contemporary Hospitality Management, 2015, v. 27, no. 6, p. 1343-1364 